\title{
ANALISIS IMPLEMENTASI PROGRAM BANK SAMPAH DI KOTA YOGYAKARTA
}

\section{ANALYSIS OF WASTE BANK PROGRAM IMPLEMENTATION IN YOGYAKARTA CITY}

\author{
Shafiera Amalia \\ PKP2A I Lembaga Administrasi Negara
}

\begin{abstract}
Abstrak
Pengelolaan sampah masih menjadi masalah bagi Kota Yogyakarta. Di satu sisi, Tempat Pembuangan Sampah Terakhir (TPST) Piyungan yang menjadi satu-satunya TPST bagi Kota Yogyakarta sudah tidak mampu lagi menampung sampah yang dihasilkan masyarakat. Sementara disisi yang lain, kesadaran dan perilaku masyarakat untuk memilah sampah masih belum optimal. Untuk mengatasi persoalan tersebut, pemerintah Kota Yogyakarta melaksanakan program Bank Sampah. Penelitian ini bertujuan untuk menganalisis apakah program Bank Sampah yang digulirkan oleh Pemerintah Kota Yogyakarta berhasil atau gagal. Analisis implementasi ini menggunakan penelitian kualitatif deskriptif. Metode pengumpulan data yang digunakan adalah studi pustaka, observasi dan wawancara mendalam. Hasil analisis menunjukkan bahwa kinerja outcomes dan kinerja output program Bank Sampah belum optimal. Program Bank Sampah belum berhasil mencapai tujuannya. Walaupun juga tidak dapat dikatakan program ini gagal. Luas dan kompleksnya perubahan perilaku yang diharapkan merupakan faktor utama yang mempengaruhi belum optimalnya kinerja implementasi Bank Sampah. Dengan demikian, program ini tidak boleh dihentikan. Program ini harus tetap berlanjut dan konsisten tetapi dengan penambahan kebijakan lain.
\end{abstract}

Kata Kunci : Bank Sampah, kinerja output, kinerja outcomes, Kota Yogyakarta

\begin{abstract}
The Piyungan Final Disposal which is the only final disposal for Yogyakarta City, was no longer able to accommodate the waste from Yogyakarta City. At the same time, people's awareness and practice to manage waste were lacking. To overcome these problems, the government of Yogyakarta implemented Waste Bank program. This study aims to analyze performance of Waste Bank program in Yogyakarta. Waste management has long been a problem for Yogyakarta City. This research focuses on analysing implementation of this initiative using descriptive qualitative research. Literature study, observation, and in-depth interviews were employed for data collection. The result of the analysis demonstrates the Waste Bank program had not been effective in achieving program outputs and outcomes. The Waste Bank program has not succeeded to achieve its objectives. The width and complexity of expected behavioral changes were the main factors affecting the low performance of Waste Bank implementation. This program should be continuously implemented, supported by additional policies to enhance program imlementattion.
\end{abstract}

Keywords : waste bank, output performance, outcomes performance, Yogyakarta City 


\section{A. Pendahuluan}

Pengelolaan sampah masih menjadi masalah bagi Kota Yogyakarta. Di satu sisi, Tempat Pembuangan Sampah Terakhir (TPST) Piyungan yang menjadi satusatunya TPST bagi Kota Yogyakarta sudah tidak mampu lagi menampung sampah yang dihasilkan masyarakat. Menurut Dinas PUP ESDM D.I.Yogyakarta, 12,5 hektar luas tanah TPST sudah tidak bisa lagi menampung sampah yang datang setiap hari (Tribun Jogja, Oktober 2016). Sementara di sisi yang lain, kesadaran dan perilaku masyarakat untuk memilah sampah masih belum optimal. Data BPS tahun 2013 menunjukkan bahwa 31,26\% rumah tangga di D.I.Yogyakarta telah memilah sampah, terdiri dari $13,07 \%$ rumah tangga memilah sampah dan memanfaatkannya sebagian; dan $18,19 \%$ rumah tangga memilah sampah dan kemudian dibuang. Adapun rumah tangga yang masih belum memilah sampah adalah sebanyak 68,74\%. Untuk mengatasi persoalan tersebut, Pemerintah Kota Yogyakarta melaksanakan program Bank Sampah.

Pada prinsipnya, Bank Sampah merupakan salah satu aktivitas teknis dalam menerjemahkan konsep pengelolaan sampah berbasis 3R (Reduce, Reuse, dan Recycle). Dewasa ini, pendekatan dalam pengelolaan sampah sudah bergeser dari pendekatan tradisional (reaktif) menuju pendekatan proaktif (3R). Menurut Damanhuri dan Padmi (2012), pendekatan tradisional (reaktif) merupakan penanganan limbah (sampah) setelah limbah tersebut terbentuk. Pendekatan ini dikenal juga dengan istilah pendekatan end-of-pipe atau pendekatan kumpul-angkut-buang. Sementara itu, pendekatan proaktif merupakan upaya agar dalam proses penggunaan bahan baku akan menghasilkan limbah yang seminimal mungkin, dengan tingkat bahaya yang serendah mungkin. Pendekatan ini bertujuan untuk mengendalikan atau mereduksi terjadinya limbah melalui penggunaan teknologi yang lebih bersih dan yang ramah lingkungan. Pendekatan ini dikenal pula dengan pendekatan $3 R$.

Secara umum, Bank Sampah merupakan tempat menyimpan sampah, menabung dan menghasilkan uang, sekaligus mengedukasi dan mengubah perilaku masyarakat (Randy, 2013). Tujuan utama dari Bank Sampah adalah perubahan perilaku masyarakat untuk memilah sampah. Selain itu, kehadiran Bank Sampah juga bertujuan untuk dapat mengurangi sampah yang masuk ke TPST Piyungan. Sejak tahun 2014, Pemerintah Kota Yogyakarta mendorong terbentuknya Bank Sampah di setiap Rukun Warga (RW) di Kota Yogyakarta. Hingga tahun 2016, tercatat terdapat 405 Bank Sampah yang tersebar di seluruh Kota. Secara nasional, program Bank Sampah ini dipayungi oleh dasar hukum Peraturan Menteri Negara Lingkungan Hidup RI No. 13 tahun 2012 tentang Pedoman Pelaksanaan Reduce, Reuse, dan Recycle melalui Bank Sampah.

Secara kuantitas, Kota Yogyakarta sudah memiliki banyak Bank Sampah. Dari 605 RW di Kota Yogyakarta, sudah 65,6\% RW yang memiliki Bank Sampah. Namun, terdapat pandangan bahwa sejumlah Bank Sampah ini justru belum dianggap optimal untuk mencapai tujuan. Menurut Kepala Bidang Pengembangan Kapasitas Badan Lingkungan Hidup (BLH) Kota Yogyakarta, dari 405 Bank Sampah yang sudah terbentuk, hanya sedikit Bank Sampah yang bertahan. Banyak Bank Sampah yang tidak begitu aktif dan bahkan mati suri. Hal ini diduga karena semangat kelompok masyarakat sebagai pengelola semakin berkurang. Berdasarkan hal di atas secara empiris implementasi program Bank Sampah di Kota Yogyakarta penting dan menarik untuk diteliti. Apakah memang benar program Bank Sampah di Kota Yogyakarta belum berhasil dan apa saja faktor yang menyebabkan program ini belum optimal. Hasil evaluasi ini dapat dijadikan dasar apakah program Bank Sampah ini akan dilanjutkan, dimodifikasi atau dihentikan dan diganti dengan program lain. 
Penelitian terdahulu mengenai Bank Sampah lebih banyak berfokus pada strategi, kinerja dan efektivitas pengelolaan Bank Sampah (Raharjo, Matsumoto, Ihsan, Rachman, Gustin, 2015; Aghpin, 2015; Saputri, Hanafi, Ulum, 2015). Selain itu, penelitian terdahulu mengenai Bank Sampah lebih banyak mendeskripsikan bahwa kehadiran Bank Sampah dapat meningkatkan kesadaran, kepedulian, perubahan perilaku dan partisipasi masyarakat dalam mengelola sampah (Bachtiar, Hanafi dan Rozikin, 2013; Syafrini, 2013; Candra, Handoyo, 2014; Purwanti, Sumartono, Haryono, 2015). Penelitian-penelitian sebelumnya lebih melihat Bank Sampah sebagai kegiatan masyarakat yang diinisiasi murni oleh masyarakat.

Sementara itu, penelitian yang memandang Bank Sampah sebagai kebijakan belum banyak dilakukan. Adapun maksud Bank Sampah sebagai kebijakan adalah Bank Sampah yang dibentuk tidak lagi murni inisiatif masyarakat, tetapi sudah terdapat intervensi dari pemerintah untuk mendorong bahkan memaksa masyarakat untuk mendirikan Bank Sampah. Oleh karena itu, penelitian ini memandang bahwa Bank Sampah merupakan salah satu kebijakan/program yang dikeluarkan oleh pemerintah, khususnya pemerintah daerah. Sehingga dapat dilihat bagaimana implementasinya di masyakarat. Oleh karena itu, penelitian ini akan mengisi kekosongan penelitian mengenai kebijakan/program Bank Sampah di Indonesia, terutama dari aspek kinerja implementasi kebijakan/program.

Berdasarkan latar belakang di atas, ada dua pertanyaan penelitian yang akan dicari jawabannya melalui penelitian ini, yaitu:

1. Bagaimana kinerja implementasi Program Bank Sampah di Kota Yogyakarta?

2. Faktor-faktor apa saja yang mempengaruhi implementasi Program Bank Sampah di Kota Yogyakarta?

\section{B. Tinjauan Pustaka}

\section{Implementasi Kebijakan}

Implementasi kebijakan merupakan bagian dari siklus kebijakan publik. Grindle (1980) mengemukakan bahwa implementasi kebijakan memiliki fungsi agar kegiatan yang dilaksanakan oleh pemerintah dapat mewujudkan tujuan kebijakan yang diharapkan. Mazmanian dan Sabatier (1983) mengemukakan bahwa implementasi merupakan pelaksanaan keputusan kebijakan. Pelaksanaan ini biasanya dimasukkan dalam undang-undang namun bisa juga berupa perintah eksekutif atau keputusan pengadilan yang penting. Menurut Purwanto dan Sulistyastuti (2012), implementasi kebijakan merupakan kegiatan untuk mendistribusikan keluaran (output) kebijakan yang dilakukan oleh implementor kebijakan kepada kelompok sasaran kebijakan untuk dapat mewujudkan tujuan kebijakan yang telah ditetapkan.

Menurut Ripley (1985) dalam Purwanto dan Sulistyastuti (2012), proses implementasi kebijakan merupakan suatu proses di mana tujuan dan sasaran kebijakan dikonkritkan oleh implementator kebijakan menjadi keluaran (output) kebijakan yang dirasakan oleh kelompok sasaran. Proses ini bukan hanya menghasilkan keluaran (output) saja, tetapi juga memberikan dampak bagi kelompok sasaran, baik dampak langsung, dampak jangka menengah dan dampak jangka panjang. Dengan demikian, proses implementasi kebijakan merupakan delivery mechanism untuk memastikan output atau keluarankeluaran kebijakan sampai pada benefeciaries sehingga suatu kebijakan dapat menghasilkan policy outcomes sebagaimana yang diharapkan. 
Pada studi kebijakan klasik, para ahli berpendapat bahwa tahapan tersulit dalam proses kebijakan adalah tahap perumusan kebijakan. Tahap implementasi kebijakan merupakan tahapan yang akan terlaksana begitu saja setelah kebijakan ditetapkan. Namun pada kenyataannya, implementasi kebijakan tidak berjalan sempurna. Ada banyak faktor yang menyebabkan suatu kebijakan gagal ketika dilaksanakan. Oleh karena itu, sangat penting untuk dapat menilai kinerja implementasi kebijakan, apakah implementasi kebijakan tersebut berhasil atau gagal dan faktor-faktor apa saja yang menyebabkan implementasi kebijakan tersebut berhasil atau gagal. Purwanto dan Sulistyastuti (2012) mengemukakan ada dua aspek yang diukur untuk dapat menilai apakah kebijakan tersebut berhasil atau gagal. Aspek tersebut adalah keluaran (output) dan dampak (outcomes) kebijakan.

\section{Kinerja Implementasi Program} Bank Sampah dalam Kerangka Pengelolaan Sampah Rumah Tangga dan Sampah Sejenis Berbasis 3R (Reduce, Reuse dan Recycle)

Sampah merupakan residu (sisa) dari berbagai aktivitas manusia yang tidak lagi digunakan. Menurut Tchobanoglous (1993) dalam Yuliani, dkk. (2012) sampah buangan berasal dari kegiatan manusia dan hewan yang tidak diinginkan. Sementara itu, Hadiwijoyoto (1983) masih di dalam Yuliani, dkk. (2012) mengemukakan bahwa sampah merupakan salah satu produk dari kegiatan manusia yang merupakan sumber pengotoran lingkungan. Di dalam Undang-Undang Nomor 18 tahun 2008 tentang Pengelolaan Sampah disebutkan bahwa sampah adalah sisa kegiatan sehari-hari manusia dan/atau proses alam yang berbentuk padat. Di dalam UU 18 tahun 2008, juga disebutkan bahwa ada tiga jenis sampah, yaitu sampah rumah tangga, sampah sejenis rumah tangga dan sampah spesifik. Dalam tulisan ini, jenis sampah yang akan dibahas adalah jenis sampah rumah tangga dan sejenis sampah rumah tangga.

Menurut Damanhuri dan Padmi (2010) ada dua pendekatan yang digunakan dalam pengelolaan sampah rumah tangga dan sampah sejenis rumah tangga, yaitu:

a) Pendekatan Reaktif. Pendekatan ini dikenal juga dengan istilah pendekatan end of pipe atau kumpul-angkut-buang. Pendekatan ini menekankan penanganan sampah yang dilakukan setelah sampah tersebut terbentuk. Sampah yang berada di sumber sampah (rumah tangga dan berbagai tempat umum) dikumpulkan pada lokasi tempat pembuangan sampah sementara dan kemudian diangkut ke tempat pengolahan sampah akhir tanpa melalui proses pemilahan dan pengolahan.

b) Pendekatan Proaktif. Pendekatan ini dikenal dengan istilah proses bersih atau teknologi bersih atau pendekatan 3R, yaitu Reduce, Reuse, dan Recycle. Pendekatan ini merupakan upaya agar dalam proses penggunaan bahan baku akan menghasilkan limbah/ sampah yang seminimal mungkin, dengan tingkat bahaya yang serendah mungkin. Pendekatan ini menekankan pengurangan, pemilahan dan pengolahan sampah pada sumbernya sebelum diproses akhir di TPA.

Pendekatan reaktif dalam pengelolaan sampah sudah tidak tepat dan ditinggalkan banyak negara. Pendekatan ini berkontribusi terhadap pencemaran lingkungan. Selain itu, pendekatan kumpul-angkut-buang tidak 
efisien, diperlukan biaya yang besar untuk melakukan pengumpulan dan pengolahan sampah setiap hari. Indonesia sudah mengadopsi pendekatan 3R yang tertuang dalam regulasi pengelolaan sampah, yaitu UndangUndang Nomor 18 tahun 2008 tentang Pengelolaan Sampah dan Peraturan Pemerintah Nomor 81 tahun 2012 tentang Pengelolaan Sampah Rumah Tangga dan Sampah Sejenis Sampah Rumah Tangga.

Pendekatan 3R dalam UndangUndang No. 18 tahun 2008 dan PP No. 81 tahun 2012 diterjemahkan dalam dua kegiatan utama, yaitu :

a) Pengurangan sampah yang terdiri dari kegiatan pembatasan timbulan sampah, pendauran ulang sampah, dan pemanfaatan kembali sampah.

b) Penanganan sampah yang terdiri dari kegiatan pemilahan, pengumpulan, pengangkutan, pengolahan, dan pemrosesan akhir sampah.

Selain itu, kedua regulasi ini juga menyebutkan bahwa kegiatan pengurangan dan penanganan sampah bukan hanya dilakukan oleh pemerintah, tetapi juga oleh pihak swasta dan masyarakat. Masyarakat memiliki kewajiban untuk melakukan pembatasan timbulan sampah, pendauran ulang sampah, pemanfaatan kembali sampah, pemilahan sampah dan pengolahan sampah.

Bank Sampah merupakan salah satu inisiatif untuk mendorong kesadaran dan mengubah perilaku masyarakat untuk melaksanakan kewajibannya terkait pengelolaan sampah. Bank Sampah pertama kali diperkenalkan oleh Bambang Suwerda di Badegan, Bantul. Suwerda (2012) dalam Saputri, Hanafi dan Ulum (2015) mengemukakan bahwa secara teknis Bank Sampah merupakan suatu tempat di mana terjadi kegiatan pelayanan terhadap penabung sampah yang dilakukan oleh teller Bank Sampah. Penabung dalam hal ini adalah seluruh warga baik secara individual maupun kelompok, menjadi anggota penabung sampah yang dibuktikan dengan adanya kepemilikkan nomor rekening, dan buku tabungan sampah, serta berhak atas hasil tabungan sampahnya. Pengelolaan sampah dengan sistem tabungan sampah di Bank Sampah, menekankan pentingnya warga memilah sampah seperti yang dikembangkan dalam pengelolaan sampah dengan sistem mandiri dan produktif.

Inisiatif ini banyak diadopsi oleh daerah-daerah lain di Indonesia. Penerapan Bank Sampah ini dapat dikatakan berhasil sebagai kebijakan pendorong kesadaran dan perubahan perilaku masyarakat dalam mengelola (memilah dan mengolah) sampah. Bila sampah sudah terkelola dengan baik di sumbernya (di masyarakat) maka volume sampah yang masuk ke TPA akan berkurang. Penelitian yang dilakukan oleh Bachtiar, Hanafi Dan Rozikin (2013) di Koperasi Bank Sampah Malang (BSM) menunjukkan bahwa penerapan BSM sedikit demi sedikit mengubah cara pandang dan perilaku warga Kota Malang dalam mengelola sampah. Pada tahun 2013, total nasabah BSM sekitar 23.000 orang. Total sampah yang terambil per hari dari nasabah mencapai 2,5 ton/hari dengan transaksi sekitar 3-4 juta rupiah. Dengan keberadaan BSM, jumlah pembuangan sampah ke TPA mengalami penurunan yang signifikan, yaitu sekitar $50 \%$.

Berdasarkan uraian di atas, maka penulis merumuskan indikator ukuran kinerja outcomes dari program Bank Sampah di Kota Yogyakarta adalah jumlah sampah yang masuk ke TPA Piyungan. Jika jumlah sampah dari Kota Yogyakarta yang masuk ke TPA Piyungan berkurang sesuai dengan SPM yang ditetapkan maka program Bank Sampah berhasil. Namun bila jumlah sampah dari Kota Yogyakarta 
yang masuk ke TPA Piyungan tetap atau justru bertambah maka program Bank Sampah ini belum berhasil.

\section{Indikator Kinerja Output Imple- mentasi Program Bank Sampah}

Menurut Purwanto dan Sulistyastuti (2012) kinerja output merupakan akibat/konsekuensi langsung yang dirasakan oleh anggota masyarakat sasaran karena dilaksanakan suatu program. Ada beberapa indikator yang dapat digunakan untuk menilai kualitas keluaran kebijakan, yaitu:

a. Akses, indikator ini digunakan untuk dapat mengetahui apakah program atau kebijakan yang dilaksanakan mudah untuk dijangkau oleh masyarakat.

b. Cakupan (coverage), indikator ini digunakan untuk mengetahui seberapa besar kelompok sasaran yang sudah dapat dijangkau oleh program atau kebijakan yang dilaksanakan.

c. Frekuensi, indikator ini digunakan untuk mengetahui seberapa sering kelompok sasaran dapat memperoleh pelayanan yang dijanjikan oleh program atau kebijakan yang dilaksanakan.

d. Bias, indikator ini digunakan untuk mengetahui apakah terdapat penyimpangan kelompok sasaran yang memperoleh manfaat dari program atau kebijakan yang dilaksanakan. Secara spesifik maksudnya adalah apakah kelompok sasaran yang menerima manfaat benar yang membutuhkan program tersebut atau tidak, yang memperoleh manfaat bukan kelompok yang membutuhkan program tersebut.

e. Service delivery (ketepatan layanan), indikator ini digunakan untuk mengetahui apakah imple-mentasi program atau kebijakan dilaksanakan tepat waktu atau terlambat. f. Akuntabilitas, indikator ini digunakan untuk mengetahui apakah implementor program atau kebijakan melaksanakan tugasnya kepada kelompok sasaran dengan dapat dipertanggungjawabkan atau tidak.

g. Kesesuaian antara program dan kebutuhan, indikator ini digunakan untuk mengetahui apakah berbagai keluaran (output) program atau kebijakan yang dilaksanakan bagi kelompok sasaran memang sesuai dengan kebutuhan mereka atau tidak.

Dalam konteks program Bank Sampah, kinerja output-nya adalah akibat apa yang diterima oleh kelompok masyarakat dengan diimplementasikan program Bank Sampah di Kota Yogyakarta. Penulis menetapkan beberapa indikator kinerja output untuk menilai keberhasilan program Bank Sampah. Indikator tersebut adalah indikator akses, frekuensi, dan cakupan (coverage).

Indikator akses dipilih karena salah satu tujuan dari program Bank Sampah adalah untuk mengubah perilaku individu masyarakat untuk dapat memilah sampah yang diproduksi. Oleh karenanya, program Bank Sampah ini harus dapat menjangkau seluruh lapisan masyarakat, baik masyarakat kelas bawah maupun masyarakat kelas menengah ke atas. Dalam penelitiannya, Syafrini (2013) mengemukakan bahwa selama ini terdapat stereotype bahwa sampah identik dengan kelas bawah dan sumber pendapatan bagi pemulung. Seluruh anggota masyarakat harus dilibatkan untuk dapat menjadi anggota Bank Sampah dan memperoleh pengetahuan mengenai pemilahan dan pengolahan sampah dari Bank Sampah. Indikator frekuensi dipilih karena indikator ini dapat menjelaskan konsistensi pengelolan Bank Sampah 
untuk melayani warga dalam menabung sampah atau memberikan pengetahuan dan keterampilan pengelolaan sampah kepada warga. Konsistensi ini penting untuk menjaga semangat masyarakat dalam memilah dan mengolah sampah. Menurut penelitian yang dilakukan oleh Bachtiar, Hanafi, dan Rozikin (2013) menjaga semangat masyarakat untuk memilah dan mengolah sampah penting dilakukan oleh Bank Sampah karena nilai rupiah sampah sangat kecil. Dan terakhir, indikator cakupan (coverage) dipilih juga berdasarkan pertimbangan tujuan perubahan perilaku masyarakat dalam mengelola sampah. Semakin banyak warga masyarakat yang menjadi nasabah Bank Sampah maka akan semakin banyak warga yang menyadari pentingnya pemilahan dan pengolahan sampah dan berusaha mengubah perilakunya untuk memilah dan mengolah sampah.

\section{Standar Pelayanan Minimal Pengu- rangan Sampah Perkotaan}

Setelah bagian sebelumnya menjelaskan mengenai indikator yang digunakan untuk mengukur kinerja implementasi program Bank Sampah, bagian ini berupaya untuk menjelaskan standar output dan outcomes yang digunakan untuk dapat menjustifikasi apakah program Bank Sampah di Kota Yogyakarta berhasil atau gagal. Standar output dan outcomes yang digunakan akan mengacu pada standar pelayanan minimal bidang pekerjaan umum dan penataan ruang yang dikeluarkan oleh Kementerian Pekerjaan Umum. Dalam SPM tersebut berisikan SPM terkait pengurangan sampah yang dilakukan oleh fasilitas tempat pengolahan $3 \mathrm{R}$ di perkotaan. Bank Sampah merupakan salah satu jenis fasilitas pengurangan, pemilahan dan pengolahan sampah $3 \mathrm{R}$ tersebut.
Pada awalnya, SPM bidang pekerjaan umum dan penataan ruang diatur melalui Peraturan Menteri Pekerjaan Umum No. 14/PRT/M/2010. Menurut aturan ini, standar pelayanan minimal yang ditetapkan untuk pengurangan sampah di perkotaan adalah $20 \%$ pada tahun 2014. Cara perhitungannya adalah dengan membandingkan volume sampah yang berhasil dikurangi di tempat pengolahan sampah sementara dengan volume sampah total yang dihasilkan oleh masyarakat. Namun, dalam penerapannya, Peraturan Menteri Pekerjaan Umum No. 14/PRT/M/2010 dianggap sulit untuk diukur dan diimplementasikan. Oleh karena itu, aturan tersebut dinyatakan tidak berlaku dengan keluarnya Peraturan Menteri Pekerjaan Umum No. 01/PRT/M/2014 tentang standar pelayanan minimal bidang pekerjaan umum dan penataan ruang. Dalam peraturan terbaru, cara mengukur SPM pengurangan sampah berubah. Pengukuran SPM pengurangan sampah bukan berbasis pada jumlah sampah yang berhasil dikurangi tetapi berbasis pada persentase fasilitas pengurangan sampah yang tersedia bagi masyarakat. Adapun SPM yang ditetapkan untuk fasilitas pengurangan sampah di perkotaan adalah $20 \%$ pada tahun 2019. Sementara cara mengukurnya dapat terbagi menjadi dua aspek yaitu:

a. Mengukur persentase kemampuan fasilitas pengurangan sampah dalam melayani masyarakat;

b. Mengukur jumlah riil anggota masyarakat yang memanfaatkan fasilitas pengurangan sampah tersebut.

Penulis tetap akan menggunakan standar pelayanan minimal pengurangan sampah berdasarkan cara pengukuran Peraturan Peraturan Menteri Pekerjaan Umum No. 14/PRT/M/2010 sebagai standar pengurangan sampah 
yang masuk ke TPA karena program Bank Sampah. Hal ini dikarenakan menurut penulis cara tersebut masuk akal dan tepat untuk mengukur outcomes/ dampak tersedianya fasilitas pengurangan sampah di perkotaan. Ditambah pula tersedia data untuk dapat mengukurnya. Sementara untuk standar pelayanan minimal pengurangan sampah berdasarkan cara pengukuran Peraturan Peraturan Menteri Pekerjaan Umum No. 01/PRT/M/2014 dapat digunakan sebagai standar untuk mengukur dua indikator kinerja output, yaitu :

a. Indikator akses, yaitu sebagai standar untuk mengukur persentase kemampuan fasilitas pengurangan sampah dalam melayani masyarakat.

b. Indikator cakupan (coverage), yaitu sebagai standar untuk mengukur jumlah riil anggota masyarakat yang memanfaatkan fasilitas pengurangan sampah tersebut.

\section{Faktor Faktor yang Mempengaruhi Kinerja Implementasi Program Bank Sampah}

Penerapan paradigma 3R dalam pengelolaan sampah mensyaratkan perubahan perilaku masyarakat dalam mengelola sampah. Masyarakat sebagai produsen sampah diharuskan untuk mengelola (memilah dan mengolah) sampah untuk meminimalisir sampah yang dibuang ke tempat pembuangan akhir (TPA). Namun pada prakteknya, perubahan perilaku ini masih sulit dilakukan. Penelitian yang dilakukan oleh Fitriana dan Soedirham (2013) mengenai perilaku ibu rumah tangga dalam pengelolaan sampah di Desa Bluru Kidul RW 11 Kecamatan Sidoarjo, Kota Sidoarjo menunjukkan hasil bahwa ibu rumah tangga responden telah memiliki pengetahuan yang baik tentang pengelolaan sampah berbasis 3R. Namun demikian, ibu rumah tangga tersebut belum memiliki perilaku/tindakan pengelolaan sampah yang sesuai dengan prinsip 3R. Ada beberapa faktor yang menyebabkan pengetahuan tersebut tidak berujung pada perubahan perilaku ibu rumah tangga dalam mengelola sampah, yaitu kurangnya fasilitas dan keterbatasan waktu karena banyak ibu rumah tangga yang bekerja.

Penelitian lain terkait perilaku masyarakat dalam mengelola sampah dilakukan oleh Setyowati dan Mulasari (2013). Penelitian ini berjudul pengetahuan dan perilaku ibu rumah tangga dalam pengelolaan sampah plastik. Penelitian dilakukan di Dusun Kedesan, Desa Kradenan, Kecamatan Kaliwungu, Kabupaten Semarang. Hasil penelitian menunjukkan bahwa ada korelasi positif antara pengetahuan dengan perilaku ibu rumah tangga dalam mengelola sampah plastik. Selain itu, hasil penelitian menunjukkan bahwa sebagian besar responden masih memiliki pengetahuan yang kurang dan perilaku pengelolaan sampah plastik yang kurang baik dan tidak sesuai dengan prinsip 3R.

Sementara itu, Agamuthu (2011) dalam Mohamad, Idris, dan Mamat (2012) mengungkapkan bahwa masyarakat Malaysia sudah memiliki kesadaran pentingnya melakukan daur ulang sampah. Namun, masih sangat sedikit yang mempraktekkan daur ulang sampah karena berbagai alasan. Beberapa alasannya adalah kurangnya insentif dan kurangnya motivasi terus menerus dalam melakukan daur ulang sampah. Lebih lanjut, Mohamad, Idris, dan Mamat (2012) menyimpulkan bahwa ada lima alasan utama mengapa praktek daur ulang sampah masih sedikit dilakukan, yaitu keterbatasan waktu, fasilitas tidak memadai, tidak tertarik melakukan daur ulang, tidak ada insentif/uang, dan tidak ada material sampah yang cukup untuk melakukan daur ulang.

Penelitian di atas menunjukkan bahwa perubahan perilaku masyarakat 
untuk mengelola sampah sulit dilakukan karena berbagai alasan. Alasan tersebut diantaranya adalah kurangnya sosialisasi dan penyuluhan, kurangnya fasilitas dan kurangnya insentif. Program Bank Sampah yang dilaksanakan di Kota Yogyakarta salah satunya bertujuan untuk mengubah perilaku masyarakat dalam mengelola sampah. Untuk itu, program ini telah berupaya untuk meminimalisir alasan masyarakat tidak mau mengubah perilakunya. BLH kota dan pengelola Bank Sampah memberikan sosialisasi dan penyuluhan terkait pengelolaan sampah, memberikan fasilitas pengelolaan sampah (tas pilah, timbangan, komposter, tempat sampah terpisah, dst.), dan memberikan insentif bagi nasabah masyarakat yang memilah dan menyetorkan sampahnya dengan sejumlah nilai uang. Penulis berpendapat bahwa perubahan perilaku masyarakat yang diharapkan terjadi dengan adanya Bank Sampah adalah perubahan perilaku yang luas, sehingga memang sulit untuk dilakukan dan memerlukan waktu yang cukup panjang. Oleh karenanya, penulis menetapkan bahwa faktor yang akan mempengaruhi kinerja implementasi program Bank Sampah adalah sejauh mana perubahan perilaku masyarakat target dengan hadirnya Bank Sampah.

Sabatier dan Mazmanian (1983) dalam Purwanto dan Sulistyastuti (2012) mengemukakan bahwa faktor sejauh mana perubahan perilaku yang diharapkan dari implementasi kebijakan termasuk dalam kategori tractability of the problem. Kategori ini menunjukkan tingkat kesulitan masalah yang harus dipecahkan melalui implementasi suatu kebijakan. Semakin sulit masalah yang harus dipecahkan akan semakin kecil peluang keberhasilan implementasi. Semakin kompleks dan luas perubahan perilaku masyarakat target yang diharapkan dari implementasi kebijakan maka akan semakin sulit kebijakan tersebut dilaksanakan. Pendapat Sabatier dan Mazmanian ini senada dengan pendapat Grindle
(1980) yang mengemukakan bahwa derajat perubahan perilaku masyarakat target yang diharapkan dari implementasi suatu kebijakan merupakan salah satu faktor yang mempengaruhi implementasi kebijakan. Grindle (1980) mencontohkan bahwa kebijakan pengenalan teknologi pertanian baru kepada petani sangat membutuhkan adaptasi dan perubahan perilaku petani. Sementara program penyediaan perumahan bagi masyarakat berpendapatan rendah hanya membutuhkan sedikit perubahan perilaku masyarakat sasaran.

Dengan demikian, penulis berpendapat bahwa program Bank Sampah yang dilakukan oleh Kota Yogyakarta termasuk dalam kebijakan yang sulit untuk diimplementasikan. Hal ini dikarenakan program ini bertujuan untuk mengubah perilaku masyarakat secara siginifikan dari yang awalnya tidak memilah dan mengolah sampah menjadi harus memilah dan mengolah sampah. Tingginya tingkat kesulitan implementasi program Bank Sampah ini akan mempengaruhi keberhasilan program ini.

\section{Metode Penelitian}

Metode penelitian yang digunakan dalam penelitian ini adalah pendekatan kualitatif. Jenis penelitian yang digunakan adalah jenis penelitian deskriptif. Teknik pengumpulan data yang digunakan adalah teknik studi pustaka, observasi dan wawancara mendalam. Dalam penelitian ini, data yang diperoleh akan dianalisis secara deskriptif kualitatif yaitu dengan memahami dan merangkai data yang telah dikumpulkan untuk menggambarkan secara mendalam mengenai objek yang diteliti; disusun secara sistematis, kemudian ditarik kesimpulan. 


\section{Kinerja Implementasi Program Bank Sampah}

\section{Kinerja Output Program Bank Sampah}

\section{a. Indikator Akses}

Indikator akses digunakan untuk dapat mengetahui apakah program atau kebijakan yang dilaksanakan mudah untuk dijangkau oleh masyarakat. Secara lebih spesifik, Purwanto dan Sulistyastuti (2012) mengemukakan bahwa mengukur indikator akses dapat diketahui dari apakah implementator kebijakan mudah dihubungi masyarakat bila membutuhkan informasi dan pengaduan, apakah semua anggota masyarakat memiliki kesempatan yang sama terlibat dan memperoleh manfaat dari kebijakan atau program, dan apakah lokasi/tempat pelaksanaan kebijakan atau program jelas dan mudah dijangkau oleh masyarakat.

Program Bank Sampah merupakan salah satu program pengelolaan sampah mandiri berbasis masyarakat. Oleh karenanya, program Bank Sampah di Kota Yogyakarta dilaksanakan bersama antara pemerintah kota (Badan Lingkungan Hidup) dengan warga masyarakat. Badan Lingkungan Hidup (BLH) Kota Yogyakarta mendorong, mendampingi dan memfasilitasi warga di setiap RW untuk membentuk Bank Sampah. Sementara itu, warga masyarakat yang membentuk dan mengelola Bank Sampah secara mandiri. Hal ini berarti bahwa pengelola Bank Sampah adalah warga masyarakat di RW tersebut secara sukarela. Dengan demikian, maka implementator Bank Sampah di masyarakat akan mudah dihubungi warga untuk meminta informasi terkait penge- lolaan sampah karena warga sudah mengenal dengan baik pengelola Bank Sampah dan pengelola berdomisili dekat dengan warga.

Berikutnya, menurut Sucipto (2012) dalam Marwati (2013) sebagai model pengelolaan sampah mandiri dan berbasis masyarakat maka program Bank Sampah harus melibatkan seluruh lapisan masyarakat. Oleh karena itu, Bank Sampah juga dirancang untuk melibatkan seluruh warga masyarakat yang ada di RW tersebut. Seluruh anggota masyarakat di RW tersebut, baik dari kalangan ekonomi menengah ke atas ataupun dari kalangan menengah ke bawah dapat terlibat aktif menjadi pengelola atau nasabah Bank Sampah. Misalnya berdasarkan hasil wawancara dengan pengelola Bank Sampah Lintas Winongo diketahui bahwa nasabah Bank Sampah Lintas Winongo adalah sebanyak $230 \mathrm{KK}$ dari $340 \mathrm{KK}(67,6 \%)$ yang ada di RW tersebut. Pengelola justru mengharapkan semua KK di RW tersebut dapat menjadi nasabah Bank Sampah.

Pemerintah Kota Yogyakarta menargetkan setiap RW di Kota Yogyakarta dapat memiliki Bank Sampah. Hal ini dimaksudkan agar Bank Sampah berada dekat dengan masyarakat. Sampai tahun 2016 ini, sudah terbentuk 405 Bank Sampah (67\%) dari $605 \mathrm{RW}$ yang ada di Kota Yogyakarta. Berikut ditampilkan data jumlah Bank Sampah yang ada di setiap kecamatan di Kota Yogyakarta.

Tabel 1. Jumlah Bank Sampah yang Ada di Setiap Kecamatan di Kota Yogyakarta

\begin{tabular}{llccc}
\hline No. & Kecamatan & $\begin{array}{c}\text { Jumlah } \\
\text { RW }\end{array}$ & $\begin{array}{c}\text { Jumlah } \\
\text { Bank } \\
\text { Sampah }\end{array}$ & $\%$ \\
\hline 1. & Mantrijeron & 55 & 20 & $36 \%$ \\
2. & Kraton & 43 & 23 & $53 \%$ \\
3. & Mergangsan & 60 & 35 & $58 \%$ \\
\hline
\end{tabular}




\begin{tabular}{clccc}
\hline No. & Kecamatan & $\begin{array}{c}\text { Jumlah } \\
\text { RW }\end{array}$ & $\begin{array}{c}\text { Jumlah } \\
\text { Bank } \\
\text { Sampah }\end{array}$ & \% \\
\hline 4. & Umbulharjo & 87 & 77 & $89 \%$ \\
\hline 5. & Kota Gede & 40 & 35 & $88 \%$ \\
\hline 6. & Gondokusuman & 65 & 39 & $60 \%$ \\
\hline 7. & Danurejan & 43 & 28 & $65 \%$ \\
\hline 8. & Pakualaman & 19 & 16 & $84 \%$ \\
\hline 9. & Gondomanan & 31 & 18 & $58 \%$ \\
\hline 10. & Ngampilan & 21 & 12 & $57 \%$ \\
11. & Wirobrajan & 34 & 27 & $79 \%$ \\
\hline 12. & Gedongtengen & 36 & 13 & $36 \%$ \\
13. & Jetis & 37 & 27 & $73 \%$ \\
\hline 14. & Tegalrejo & 34 & 35 & $103 \%$ \\
\hline & Jumlah & $\mathbf{6 0 5}$ & $\mathbf{4 0 5}$ & $\mathbf{6 7 \%}$ \\
\hline \multicolumn{4}{l}{ Sumber : Hasil Pengolahan Data, 2016. } \\
\hline
\end{tabular}

Dari Tabel 1 di atas terlihat bahwa seluruh kecamatan di Kota Yogyakarta telah memiliki Bank Sampah. Kecamatan Tegalrejo dan Umbulharjo merupakan kecamatan yang memiliki proporsi Bank Sampah dengan jumlah RW yang paling besar. Sementara Kecamatan Mantrijeron dan Gedongtengen merupakan kecamatan yang memiliki proporsi Bank Sampah dengan jumlah RW yang paling kecil. Dengan demikian, Bank Sampah ini sudah sangat mudah dijangkau oleh anggota masyarakat karena sudah terbentuk di seluruh kecamatan dan di sebagian besar RW di Kota Yogyakarta.

Pemerintah Kota Yogyakarta menargetkan 1 RW memiliki 1 sampah. Artinya bahwa 1 Bank Sampah akan melayani warga RW tersebut. Kota Yogyakarta memiliki 129.252 KK dan 605 RW. ${ }^{1}$ Bila dirata-ratakan, 1 RW memiliki 213 KK. Dengan demikian, seluruh Bank Sampah di Kota Yogyakarta akan mampu melayani 86.265 KK atau sebanyak $66,7 \%$ dari seluruh KK yang ada di Kota Yogyakarta. Dengan demikian, jumlah fasilitas pengurangan sampah (Bank Sampah) yang ada sudah melebihi SPM kemampuan fasilitas pengura- ngan sampah melayani masyarakat, yaitu $20 \%$.

\section{b. Indikator Frekuensi}

Indikator frekuensi digunakan untuk mengetahui seberapa sering kelompok sasaran dapat memperoleh pelayanan yang dijanjikan oleh program atau kebijakan yang dilaksanakan. Dalam konteks Bank Sampah, frekuensi pelayanan terlihat dari seberapa sering Bank Sampah dibuka dan memberikan pelayanan kepada nasabah. Menurut wawancara dengan pengelola Bank Sampah Lintas Winongo, tidak ada Bank Sampah di Kota Yogyakarta yang buka setiap hari, tetapi 1 hari setiap minggu. Hari dan waktunya merupakan hasil kesepakatan antara pengelola dengan masyarakat nasabah. Alasan Bank Sampah hanya dibuka seminggu sekali adalah untuk memberi ruang bagi pengelola untuk melakukan aktivitasnya yang lain dan memberi waktu bagi nasabah untuk mengumpulkan sampah yang telah dipilah. Misalnya Bank Sampah Lintas Winongo buka setiap hari minggu pukul 08.00 - 12.00, Bank Sampah Surolaras buka setiap hari sabtu pukul 10.00 - 12.00, dan Bank Sampah Mitra Insani buka setiap hari Kamis pukul $09.00-12.00$.

Dari hasil wawancara dengan pihak BLH Kota Yogyakarta, walaupun hanya dibuka satu hari setiap minggu, banyak pengelola Bank Sampah yang tidak konsisten untuk memberikan pelayanan setiap hari yang sudah ditentukan. Banyak juga pengelola Bank Sampah yang masih belum memiliki komitmen kuat untuk membuka dan memberikan pelayanan Bank Sampah secara rutin. Hal ini salah satu yang

\footnotetext{
${ }^{1}$ Diolah dari data Kecamatan Dalam Angka, 2016.
} 
menyebabkan banyak Bank Sampah yang terbentuk tidak aktif dan menjadi mati suri. Menurut pengelola Bank Sampah Lintas Winongo, dari seluruh Bank Sampah yang terbentuk hanya sekitar 10\% (40 Bank Sampah) yang aktif dan konsisten melayani masyarakat nasabah.

\section{c. Indikator Cakupan (Coverage)}

Indikator cakupan digunakan untuk mengetahui seberapa besar kelompok sasaran yang sudah dapat dijangkau oleh program atau kebijakan yang dilaksanakan. Pada program Bank Sampah, indikator ini dapat diukur dari seberapa besar jumlah Kepala Keluarga (KK) yang menjadi nasabah Bank Sampah dibandingkan dengan jumlah KK yang ada di lingkungan tersebut. Berikut ditampilkan data perbandingan antara jumlah KK yang menjadi nasabah Bank Sampah.

Tabel 2. Jumlah KK yang Menjadi Nasabah Bank Sampah di Setiap Kecamatan di Kota Yogyakarta

\begin{tabular}{llrrr}
\hline No. & Kecamatan & $\begin{array}{c}\text { Jumlah } \\
\text { KK }\end{array}$ & $\begin{array}{c}\text { Jumlah } \\
\text { Nasabah } \\
\text { Bank } \\
\text { Sampah }\end{array}$ & \% \\
\hline 1. & Mantrijeron & 11415 & 1160 & $10 \%$ \\
\hline 2. & Kraton & 7099 & 832 & $12 \%$ \\
\hline 3. & Mergangsan & 10079 & 1597 & $16 \%$ \\
\hline 4. & Umbulharjo & 21007 & 2850 & $14 \%$ \\
\hline 5. & Kota Gede & 10147 & 1660 & $16 \%$ \\
\hline 6. & Gondokusuman & 13122 & 1956 & $15 \%$ \\
\hline 7. & Danurejan & 6835 & 922 & $13 \%$ \\
\hline 8. & Pakualaman & 3461 & 367 & $11 \%$ \\
\hline 9. & Gondomanan & 4780 & 685 & $14 \%$ \\
\hline 10. & Ngampilan & 5762 & 803 & $14 \%$ \\
\hline 11. & Wirobrajan & 8694 & 886 & $10 \%$ \\
\hline 12. & Gedongtengen & 6587 & 608 & $9 \%$ \\
\hline 13. & Jetis & 8745 & 1178 & $13 \%$ \\
\hline 14. & Tegalrejo & 11519 & 1059 & $9 \%$ \\
\hline & Jumlah & $\mathbf{1 2 9 2 5 2}$ & $\mathbf{1 6 5 6 3}$ & $\mathbf{1 3 \%}$ \\
\hline Sumber : Hasil Pengolahan Data, 2016. &
\end{tabular}

Dari Tabel 2 di atas terlihat bahwa secara keseluruhan, baru 16.563 KK (13\%) dari $129.252 \mathrm{KK}$ di Kota Yogyakarta yang menjadi nasabah Bank Sampah. Kecamatan
Mergangsan dan Kota Gede merupakan kecamatan yang memiliki proporsi nasabah Bank Sampah dengan jumlah KK yang paling besar (16\%). Kecamatan Gedongtengen dan Tegalrejo merupakan kecamatan yang memiliki proporsi nasabah Bank Sampah dengan jumlah KK yang paling kecil (9\%). Dengan demikian, jumlah riil anggota masyarakat yang memanfaatkan fasilitas pengurangan sampah (Bank Sampah) belum memenuhi SPM jumlah masyarakat pengguna fasilitas pengurangan sampah, yaitu 20\%. Hal ini menunjukkan bahwa partisipasi masyarakat untuk menjadi nasabah Bank Sampah masih rendah. Rendahnya partisipasi masyarakat ini juga menunjukkan bahwa kesadaran dan perilaku masyarakat untuk memilah dan mengolah sampah masih rendah.

\section{Kinerja Outcomes Program Bank Sampah}

Indikator outcomes program Bank Sampah yang telah ditetapkan sebelumnya adalah jumlah sampah yang masuk ke TPA Piyungan. Jika jumlah sampah dari Kota Yogyakarta yang masuk ke TPA Piyungan berkurang sesuai dengan SPM yang ditetapkan maka program Bank Sampah berhasil. Namun bila jumlah sampah dari Kota Yogyakarta yang masuk ke TPA Piyungan tetap atau justru bertambah maka program Bank Sampah ini belum berhasil. Berdasarkan penelitian yang dilakukan oleh Universitas Ahmad Dahlan (2016), Bank Sampah di Kota Yogyakarta mampu mengurangi sampah sebanyak 28,76 ton / hari, atau sekitar $16 \%$ dari total sampah sebanyak 176,73 ton sampah/hari yang diproduksi oleh warga Kota Yogya-karta. Setiap Bank Sampah rata-rata dapat mengurangi sampah sebanyak $97.81 \mathrm{~kg} / \mathrm{bulan}$ atau sekitar 3,26 kg/hari sampah. Sementara 
itu, setiap individu rata-rata menabung $0,227 \mathrm{~kg}$ sampah per hari.

Dengan demikian, program Bank Sampah di Kota Yogyakarta sudah mampu untuk mengurangi jumlah sampah yang masuk ke TPA Piyungan. Hanya saja pengurangan sampahnya baru sebesar $16 \%$ dari total sampah. Kondisi ini masih belum memenuhi SPM pengurangan sampah yang ditetapkan Kementerian Pekerjaan Umum yaitu sebesar 20\%

\section{E. Faktor yang Mempengaruhi Kinerja Implementasi Program Bank Sampah}

Dari uraian di atas dapat disimpulkan bahwa kinerja outcomes dan kinerja output program Bank Sampah belum optimal. Dari segi akses, BLH Kota Yogyakarta telah berupaya untuk membentuk Bank Sampah di sebagian besar RW di Kota Yogyakarta. Namun, dari segi frekuensi, masih banyak Bank Sampah yang tidak konsisten untuk memberikan pelayanan. Sementara dari segi cakupan, masih banyak warga yang belum menjadi nasabah Bank Sampah. Partisipasi warga untuk menjadi nasabah masih rendah. Hal ini menunjukkan belum terdapat kesadaran dan perubahan perilaku masyarakat dalam mengelola sampah. Kinerja output ini mempengaruhi kinerja outcomes program Bank Sampah. Bank Sampah baru mampu mengurangi 16\% jumlah sampah yang diproduksi warga Kota Yogyakarta. Sementara standar pengurangan sampah yang ditetapkan pemerintah adalah $20 \%$. Hal ini juga berarti bahwa jumlah sampah Kota Yogyakarta yang masuk ke TPA Piyungan masih cukup besar. Dengan demikian program Bank Sampah belum berhasil mencapai tujuannya. Walaupun juga tidak dapat dikatakan program ini gagal.

Belum optimalnya implementasi program Bank Sampah yang dilakukan oleh Kota Yogyakarta dikarenakan program ini termasuk dalam kebijakan yang sulit untuk diimplementasikan. Faktor derajat perubahan perilaku masyarakat yang diharapkan dari program ini kompleks dan luas. Seperti sudah dikemukakan sebelumnya, program Bank Sampah berupaya untuk meningkatkan kesadaran dan mengubah perilaku masyarakat dari yang awalnya tidak melakukan pemilahan dan pengolahan sampah diharuskan untuk memilah dan mengolah sampah. Pihak BLH Kota Yogyakarta mengemukakan bahwa masyarakat harus merubah pola pikirnya terhadap sampah dengan menjadi masyarakat modern. Ciri masyarakat modern adalah mampu mengelola sampah dengan memilah sampah. Bila masyarakat tidak mau berubah, maka pemerintah akan kewalahan (BLH Kota Yogyakarta, 2016). Perubahan pemikiran, kebiasaan dan perilaku inilah yang sangat sulit untuk dilakukan. Pengelola Bank Sampah Lintas Winongo mengungkapkan bahwa menggugah kesadaran dan mengubah perilaku masyarakat untuk mau memilah dan mengolah sampah merupakan proses dan memerlukan waktu yang panjang.

\section{F. Penutup}

Kinerja outcomes dan kinerja output program Bank Sampah belum optimal. Program Bank Sampah belum berhasil mencapai tujuannya. Walaupun juga tidak dapat dikatakan program ini gagal. Luas dan kompleksnya perubahan perilaku yang diharapkan merupakan faktor utama yang mempengaruhi belum optimalnya kinerja implementasi Bank Sampah. Dengan demikian, program ini tidak boleh dihentikan. Program ini harus tetap berlanjut dan konsisten tetapi dengan penambahan kebijakan lain. Kebijakan lain yang dapat mendukung program Bank Sampah diantaranya adalah:

1. Penataan sistem pengumpulan dan pengangkutan sampah di Kota Yogyakarta yang juga menerapkan prinsip 
pemilahan sampah. Sampah yang dikumpulkan dan diangkut adalah sampah yang terpilah. Sampah organik dan sampah anorganik harus diangkut dengan alat pengangkutan yang berbeda.

2. Menetapkan regulasi yang mengatur kewajiban masyarakat memilah sampah dengan punishment yang jelas seperti sampah tidak akan diangkut bila tidak terpilah.

3. Pemerintah kota perlu menerapkan teknologi pengolahan bagi sampah plastik terpilah tetapi yang tidak laku dijual ke pengepul, seperti plastik kresek, pouch minyak goreng, bungkus sampo, kopi, makanan ringan, dan sebagainya. Jenis plastik ini tidak dapat diserap pengepul untuk didaur ulang. Oleh karena itu, pemerintah kota perlu memikirkan teknik pengolahan plastik tersebut dengan data jumlah KK setiap kecamatan di Kota Yogyakarta.

\section{Daftar Pustaka}

Aghpin, R., 2016, Perbandingan Efektivitas Bank Sampah di Kota Bandung dan Kota Yogyakarta, Inersia, XII (1), 8590

Bachtiar, H., Hanafi, I. dan Rozikin, M., 2013, Pengembangan Bank Sampah Sebagai Bentuk Partisipasi Masyarakat dalam Pengelolaan Sampah (Studi pada Koperasi Bank Sampah Malang), Jurnal Administrasi Publik, 3(1), 128133

Candra, T.F., dan Handoyo, P., 2014, Strategi Pemberdayaan Masyarakat dalam Praktek Bank Sampah (Studi Kasus pada Bank Sampah Bintang Mangrove di Kelurahan Gunung Anyar Tambak, Surabaya), Jurnal Paradigma, 2(2), 1-7

Fitriana, A. dan Soedirham, O., 2013, Perilaku Ibu Rumah Tangga dalam Pengelolaan Sampah di Desa Bluru Kidul RW 11 Kecamatan Sidoarjo, Jurnal Promkes, 1(2), 132-137
Grindle, M.S., 1980, Politics and Policy Implementation in The Third World, Princeton, NJ : Princeton University Press

Mazmanian, D.A., dan Sabatier, P.A., Implementation and Public Policy, University Press of America.

Mohamad, Z.F., Idris, N., Mamat, Z., 2012, Role of Religious Communities in Enhancing Transition Experiments: A Localized Strategy for Sustainable Solid Waste Management in Malaysia, Sustain Sci, 7, 237-251

Purwanti, W.S., Sumartono, Haryono, B.S., 2015, Perencanaan Masyarakat dalam Rangka Pemberdayaan Masyarakat di Kecamatan Kepanjen Kabupaten Malang, Reformasi, 5 (1), 149-159

Purwanto, Erwan Agus dan Sulistyastuti, Dyah Ratih, 2012, Implementasi Kebijakan Publik Konsep dan Aplikasinya di Indonesia, Yogyakarta : Penerbit Gava Media

Raharjo, S., Matsumoto, T., Ihsan, T., Rachman, I., dan Gustin, L., 2015, Community-Based Solid Waste Bank Program for Municipal Solid Waste Management Improvement in Indonesia : A Case Study of Padang City, J Mater Cycles Waste Manag

Saputri, M.M., Hanafi, I., dan Ulum, M.C., 2015, Evaluasi Dampak Kebijakan Pemerintah Daerah dalam Pengelolaan Sampah Melalui Program Bank Sampah, Jurnal Administrasi Publik (JAP), 3 (11), 1804-1808

Setyowati, R, dan Mulasari, S.A., 2013. Pengetahuan dan Perilaku Ibu Rumah Tangga dalam Pengelolaan Sampah Plastik, Jurnal Kesehatan Masyarakat Nasional, 7(12), 562-566

Syafrini, D., 2013, Bank Sampah : Mekanisme Pendorong Perubahan dalam Kehidupan Masyarakat (Studi Kasus: Bank Sampah Barokah Assalam Perumahan Dangau Teduh Kecamatan Lubuk Begalung Padang), Jurnal Humanis, 12(2), 155-167

Yuliani, Rohidin, Brata, B., 2012, Pengelolaan Sampah di Kecamatan 
Kota Manna Kabupaten Bengkulu Selatan Melalui Pendekatan Sosial Kemasyarakatan, Naturalis, 1(2), 95100

\section{$\underline{\text { Peraturan Perundangan }}$}

Undang Undang Nomor 18 tahun 2008 Pengelolaan Sampah. 7 Mei 2008. Lembaran Negara Republik Indonesia Tahun 2008 Nomor 69. Jakarta.

Peraturan Pemerintah Nomor 81 tahun 2012 Pengelolaan Sampah Rumah Tangga dan Sampah Sejenis Sampah Rumah Tangga. 15 Oktober 2012. Lembaran Negara Republik Indonesia tahun 2012 Nomor 188. Jakarta.

Peraturan Menteri Pekerjaan Umum No. 14/PRT/M/2010 Standar Pelayanan Minimal Bidang Pekerjaan Umum dan Penataan Ruang. 2 Desember 2010. Berita Negara Republik Indonesia tahun 2010 Nomor 587. Jakarta.

Peraturan Menteri Pekerjaan Umum No. 01/PRT/M/2014 tentang Standar Pelayanan Minimal Bidang Pekerjaan Umum dan Penataan Ruang. 27 Februari 2014. Berita Negara Republik Indonesia tahun 2014 Nomor 267. Jakarta.

\section{Website}

Damanhuri, Enri dan Tri Padmi, 2010, Pengelolaan Sampah, Diktat Kuliah TL 3104, diakses pada 18 Mei 2016 melalui

http://hmtl.itb.ac.id/wordpress/wpconte nt/uploads/2011/03/ DiktatSampah2010.pdf
Marwati, S, 2013, Pengelolaan Sampah Mandiri Berbasis Masyarakat, Bahan Sosialisasi PPM Universitas Negeri Yogyakarta, diakses pada 17 Desember 2016 melalui staff.uny.ac.id/sites/default/files/penga bdian/siti-marwati-msi/c9.pdf

Salim, Randy, 2013, Bank Sampah di Indonesia : Menabung, Mengubah Perilaku, diakses pada 28 Juni 2016 melalui

http://blogs.worldbank.org/eastasiapaci fic/id/bank-sampah-di-indonesiamenabung-mengubah-perilaku

Solusi Darurat Sampah Kota Yogyakarta : Keuntungan dan Manfaatnya, diakses pada 17 Desember 2016 melalui https://uad.ac.id/id/berita/solusidarurat-sampah-kota-yogyakartakeuntungan-dan-manfaatnya

Keberadaan Bank Sampah di Kota Yogya Dinilai Tak Maksimal, diakses pada 20 September $2016 \quad$ melalui http://jogja.tribunnews.com/2016/08/1 0/keberadaan-bank-sampah-di-kotayogya-dinilai-tak-maksimal

Kepala BLH Kota Jogja : Sampah Adalah Tanggung Jawab Pemilik Sampah, diakses pada 17 Desember 2016 melalui

http://www.jogjakota.go.id/news/Kepal a-BLH-Kota-Jogja-Sampah-AdalahTanggung-Pemilik-Sampah

Lipsus, Sampah Semakin Menggunung di TPST Piyungan, diakses pada 08 Oktober $2016 \quad$ melalui http://jogja.tribunnews.com/2015/12/3 1/lipsus-sampah-semakinmenggunung-di-tpst-piyungan 